\title{
Planta Daninha
}

Research Article

\section{Association of chemical and mechanical weed control methods during the pre-harvest of coffee crops}

\author{
Cláudio P. Ronchi* \\ a Universidade Federal de Viçosa, Campus Florestal, Florestal-MG, Brasil.
}

\author{
ARTICLE INFORMATION \\ Received: November 4, 2018 \\ Accepted: February 21, 2020 \\ Keywords: \\ Coffea arabica \\ burndown \\ herbicide \\ integrated weed management
}

\section{${ }^{*}$ Corresponding author: \\ <claudiopagotto@ufv.br>}

\section{Cite this article:}

$\mathrm{RONCHI} C \mathrm{CP}$. Association of chemical and mechanical weed control methods during the pre-harvest of coffee crops. Planta Daninha. 2020;38:e020216110. https://doi.org/10.1590/S0100-83582020380100079

\section{Conflict of Interest:}

The author declare that there is no conflict of interest regarding the publication of this manuscript.

Copyright: This is an open-access article distributed under the terms of the Creative Commons Attribution License, which permits unrestricted use, distribution, and reproduction in any medium, provided that the original author and source are credited. (a) (1)

\section{HIGHLIGHTS}

- Using soil-applied herbicides just after the brush shredder is an interesting association in the pre-harvest.

- Weed species and rain conditions should be considered when choosing weed control methods in the pre-harvest.

- Burndown operations should be the last weed control method in the pre-harvest of the coffee.

\begin{abstract}
Background: Weed control in the pre-harvest of the coffee crop is essential to enable mechanized coffee harvesting.

Objective: Testing the efficacy of pre-emergent herbicides, applied after brush shredder or desiccation operations, on the weed control during the coffee crop's pre-harvest.

Methods: Two separate trials were accomplished in commercial Coffea arabica crops in the Cerrado Mineiro Region. In the first one, oxyfluorfen and sulfentrazone were applied after either brush shredder or burndown operation; in the second, they were tested as a tank mixture with glyphosate.

Results: In the first assay, the brush shredder use, associated to the rains that follow, stimulated a sharp weed infestation during the preharvest, which was not observed in desiccated plots. A sole application of oxyfluorfen or sulfentrazone, following either brush shedder or desiccation operation, effectively controlled the weeds; however, the sequential applications on burndown areas may be needless. The applied herbicides did not intoxicate the coffee plants nor affect their growth. In the second assay, both herbicide mixtures were highly efficient on the weed control through post-emergence application during the pre-harvest, what was not observed with a sole application of glyphosate. In both experiments, a dry period during winter, associated to the operations to gather fallen coffee fruit, collectively contributed to control weeds. Differently from oxyfluorfen, the residual effect of sulfentrazone was high enough to control weed even in the beginning of the rainy season.

Conclusion: Sulfentrazone and oxyfluorfen were effective on the weed control in the pre-harvest of the coffee crop, mainly when applied after brush shedder operations.
\end{abstract}

\section{INTRODUCTION}

Brazil is the world's largest coffee producer, with a 2019 harvest estimate of 50.917 million bags
(Companhia Nacional de Abastecimento - Conab, 2019). Of the total of 2.163 million ha cultivated in the country, $56.8 \%$ are concentrated in Minas Gerais, which, consequently, is the first in the national ranking 
and will be responsible for producing alone 26.445 million bags, of which $98.8 \%$ are from Arabica coffee. Although the southern region is the main coffee producer in that state, the Cerrado Mineiro Region, which comprises the Alto Paranaíba, the Triângulo Mineiro and the Northwest of Minas Gerais, will be responsible for producing 4.902 million bags of Arabica coffee, corresponding to $18.77 \%$ of Minas Gerais production and $9.63 \%$ of national production (Conab, 2019).

One of the main characteristics of crops grown in the Cerrado Mineiro Region is that they are implanted in open rows, with 3.8 to $4.0 \mathrm{~m}$ spacing between rows, which allows mechanized cultivation and harvesting, in addition to cultural treatments, such as application of pesticides and foliar fertilizers (Santinato et al., 2008; Fernandes et al., 2012; Matiello et al., 2016). Nevertheless, the coffee tree is a perennial plant, with slow initial growth (DaMatta et al., 2007), with a relatively superficial root system and concentrated in the vicinity of the crown (Ronchi et al., 2015). Consequently, in Cerrado coffee crops there is a high exposure of soil in the inter-rows, facilitating weed infestation (Ronchi and Silva, 2018; Araújo et al., 2012).

Weeds are known to cause severe damage to coffee, due to competition for environmental resources (Ronchi and Silva, 2006; Lemes et al., 2010). In adult crops, management is carried out in the hot and rainy period (October to March), in order to avoid the impairment of vegetative growth and coffee crop yield (Blanco et al., 1982; Ronchi and Silva, 2018). However, in the pre-harvest period, weed control has as main objective of facilitating the harvesting and ensuring high efficiency of the sweeping process of ground coffee (Matiello et al., 2016; Ronchi and Silva, 2018). Furthermore, the control of weeds may contribute to the reduction of moisture on the soil surface (due to organic residues), capable of causing fermentation of grains fallen on the soil (Matiello et al., 2016).

Currently, with great concern about the attack of the coffee berry borer, and its significant damage to the yield, type and quality of the coffee harvested (among other effects), high efficiency is sought in collecting coffee during sweeping, to that there are no remaining grains in which the pest can multiply in the off-season (cultural control). In this sense, the careful management of weeds in the pre-harvest starts to play a major role in reducing the coffee berry borer attack in the next harvest (Ronchi and Silva, 2018). Equally important to ensure the efficiency of mechanized coffee sweeping are leveling the soil and the simultaneous grinding of plant residues (Matiello et al., 2016; Tavares, 2016).

Thus, the brush shredder is commonly used in coffee growing in the Cerrado, between the months of March and May, for leveling the soil surface, grinding organic waste and simultaneous control of weeds, preparing the crop for mechanized harvesting and sweeping (Matiello et al., 2016; Santinato et al, 2016; Tavares, 2016). However, as it is also common at this time for rain to occur, even if of low intensity (Araújo et al., 2012; Fernandes et al., 2016), and due to the extensive mechanized areas, weed reinfestation frequently occurs in the period between the use of the brush and the coffee harvest. Consequently, this requires the coffee grower to carry out the chemical weed control immediately before harvest in most areas. In this case, weed control is usually carried out with non-selective herbicides (glyphosate is the most used), applied in the post-emergence of the weed infestation (Ronchi and Silva, 2018).

Another option for the control of weed reinfestation in the pre-harvest would be the use of pre-emergent herbicides (Santinato et al., 2016; Ronchi and Silva, 2018). These herbicides can potentially be used in different management systems in pre-harvest of the coffee crop, represented by application immediately after using the brush shredder, after desiccation with glyphosate, or even in a tank mix with glyphosate. Despite recent advances in herbicides synthesis or formulation, few herbicide molecules are registered for use in pre-emergence in adult coffee crops (Rodrigues and Almeida, 2018; Magalhães et al., 2012). Nevertheless, the coffee producers of the Cerrado Mineiro Region rarely make use of preemergent herbicide for this crop phase, either by preference for post-emergence desiccation, or lack of knowledge and scientific research on the impact of these products on the weed species, soil characteristics and coffee plant for the different management systems.

Thus, it is believed that research with soil-applied herbicides, in different management systems in the pre-harvest period of coffee, can bring great scientific and technological contribution to the integrated management of weeds in mechanized coffee growing areas in the Cerrado. Thus, the objectives of this work were to evaluate: i) the efficacy and residual effect of the herbicides sulfentrazone and oxyfluorfen in the pre-harvest time of adult coffee crops; ii) the adequacy of the sulfentrazone and oxyfluorfen in three management systems: application immediately after 
using the brush shredder, application sequentially to glyphosate desiccation, and application in tank mixture with glyphosate; and iii) the potential harm of herbicides to the coffee crop.

\section{MATERIAL AND METHODS}

\subsection{Experimental conditions}

Two independent experiments were installed from May to December 2012 in two commercial crops on the

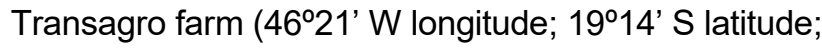
$900 \mathrm{~m}$ altitude), located in Rio Paranaíba, Minas Gerais. During the experimental period, meteorological data (minimum, maximum and average air temperatures and precipitation) were collected in instruments installed close to the experimental areas. The soil in these areas was characterized as a RedYellow Latosol, with a clay texture, whose chemical and granulometric characteristics in the $0-10 \mathrm{~cm}$ layer are shown in Table 1 . With the exception of weed management, which resulted in the treatments tested, the other cultural treatments related to fertilization,

Table 1 - Chemical and textural characteristics of soil samples in the $0-10 \mathrm{~cm}$ layer of the two experimental areas

\begin{tabular}{|c|c|c|}
\hline \multirow{2}{*}{ Characteristic } & \multicolumn{2}{|c|}{ Samples } \\
\hline & Experiment 1 & Experiment 2 \\
\hline \multicolumn{3}{|c|}{ Chemical characteristics } \\
\hline $\mathrm{pH}\left(\mathrm{H}_{2} \mathrm{O}\right)$ & 6.6 & 6.6 \\
\hline $\mathrm{pH}\left(\mathrm{CaCl}_{2}\right)$ & 5.9 & 6.1 \\
\hline$P\left(\mathrm{mg} \mathrm{dm}^{-3}\right)$ & 63.5 & 60.4 \\
\hline $\mathrm{S}-\mathrm{SO}_{4}^{--}$ & 8.0 & 9.0 \\
\hline $\mathrm{K}\left(\mathrm{cmol}_{\mathrm{c}} \mathrm{dm}^{-3}\right)$ & 1.79 & 1.14 \\
\hline $\mathrm{Ca}\left(\mathrm{cmol}_{\mathrm{c}} \mathrm{dm}^{-3}\right)$ & 5.7 & 8.0 \\
\hline $\mathrm{Mg}\left(\mathrm{cmol}_{\mathrm{c}} \mathrm{dm}^{-3}\right)$ & 3.0 & 3.5 \\
\hline $\mathrm{Al}\left(\mathrm{cmol}_{\mathrm{c}} \mathrm{dm}^{-3}\right)$ & 0.0 & 0.0 \\
\hline $\mathrm{H}+\mathrm{Al}\left(\mathrm{cmol}_{\mathrm{c}} \mathrm{dm}^{-3}\right)$ & 2.33 & 2.20 \\
\hline $\mathrm{Sb}\left(\mathrm{cmol}_{\mathrm{c}} \mathrm{dm}^{-3}\right)$ & 10.49 & 12.64 \\
\hline $\mathrm{t}\left(\mathrm{cmol}_{\mathrm{c}} \mathrm{dm}^{-3}\right)$ & 10.49 & 12.64 \\
\hline $\mathrm{T}\left(\mathrm{cmol}_{\mathrm{c}} \mathrm{dm}^{-3}\right)$ & 12.82 & 14.84 \\
\hline $\mathrm{V}(\%)$ & 81.8 & 85.2 \\
\hline $\mathrm{B}\left(\mathrm{mg} \mathrm{dm}^{-3}\right)$ & 1.16 & 1.07 \\
\hline $\mathrm{Cu}\left(\mathrm{mg} \mathrm{dm}^{-3}\right)$ & 8.5 & 18.3 \\
\hline $\mathrm{Fe}\left(\mathrm{mg} \mathrm{dm}^{-3}\right)$ & 32.0 & 37.0 \\
\hline $\mathrm{Mn}\left(\mathrm{mg} \mathrm{dm}^{-3}\right)$ & 28.2 & 27.6 \\
\hline $\mathrm{Zn}\left(\mathrm{mg} \mathrm{dm}^{-3}\right)$ & 7.05 & 9.5 \\
\hline Organic matter $\left(\mathrm{g} \mathrm{dm}^{-3}\right)$ & 56.5 & 65.0 \\
\hline Organic carbon $\left(\mathrm{g} \mathrm{dm}^{-3}\right)$ & 32.8 & 37.7 \\
\hline \multicolumn{3}{|c|}{ Textural characteristics } \\
\hline Coarse sand $\left(\mathrm{g} \mathrm{dm}^{-3}\right)$ & 11 & 16 \\
\hline Thin sand $\left(\mathrm{g} \mathrm{dm}^{-3}\right)$ & 21 & 12 \\
\hline Total sand $\left(\mathrm{g} \mathrm{dm}^{-3}\right)$ & 32 & 28 \\
\hline Clay $\left(\mathrm{g} \mathrm{dm}^{-3}\right)$ & 475 & 564 \\
\hline Silte $\left(\mathrm{g} \mathrm{dm}^{-3}\right)$ & 493 & 408 \\
\hline Textural classification & Clayey & Clayey \\
\hline
\end{tabular}

$\mathrm{P}$ - Mehlich; $\mathrm{Sb}=$ sum of bases; $\mathrm{t}=$ efective CTC; $\mathrm{T}=\mathrm{CTC}$ on $\mathrm{pH}$ 7.0; $\mathrm{V}=$ base saturation; $\mathrm{P}, \mathrm{K}, \mathrm{Na}=\left(\mathrm{HCl} 0.05 \mathrm{~mol} \mathrm{~L}^{-1}+\mathrm{H}_{2} \mathrm{SO}_{4}\right.$ $\left.0.0125 \mathrm{~mol} \mathrm{~L}^{-1}\right) ; \quad \mathrm{S}^{-\mathrm{SO}_{4}}={ }=($ calcium monobasic phosphate $\left.0.01 \mathrm{~mol} \mathrm{~L}^{-1}\right) ; \mathrm{Ca}, \mathrm{Mg}, \mathrm{Al}=\left(\mathrm{KCl} 1.0 \mathrm{~mol} \mathrm{~L}^{-1}\right) ; \mathrm{H}+\mathrm{Al}=$ (buffer solution SMP a pH 7.5); Organic matter = calorimetric method; $\mathrm{Cu}$, $\mathrm{Fe}, \mathrm{Mn}, \mathrm{Zn}=$ (DTPA pH 7.3); $\mathrm{B}=$ hot water. phytosanitary control, among others, carried out in the experimental areas, followed the agronomic practices adopted on the farm, common in mechanized coffee farming (Matiello et al., 2016).

\subsection{Experiment 1}

Experiment 1 was carried out in a fertigated crop (Coffea arabica cv. Catuaí Vermelho IAC 144) with 5.5 years of age, implanted in the $3.8 \times 0.5 \mathrm{~m}$ spacing, in December 2006. The design used was that of randomized blocks, with seven treatments and three repetitions. Each experimental unit consisted of a $10 \mathrm{~m}$ long coffee row, containing 20 plants and totaling an area of $38.0 \mathrm{~m}^{2}$. Two weed management systems were tested: soil-applied herbicides immediately after using the brush shredder or sequentially with glyphosate desiccation, with an interval of 11 days between operations.

The treatments were: control (without pre-harvest weed control operation); just brush shredder; brush shredder followed by application of oxyfluorfen $\left(0.720 \mathrm{~kg}\right.$ a.i. ha- $\left.{ }^{-1}\right) ;$ brush shredder followed by application of sulfentrazone $\left(0.600 \mathrm{~kg}\right.$ a.i. ha- $\left.{ }^{-1}\right)$; only glyphosate desiccation $(0.720 \mathrm{~kg}$ a.i. ha-1 $)$; glyphosate desiccation followed by application of oxyfluorfen; and desiccation with glyphosate followed by application of sulfentrazone. The glyphosate desiccation operations, the use of the brush shredder and the application of pre-emergence action herbicides were carried out on 5/24/2012, 5/31/2012 and 6/4/2012, respectively. It is important to emphasize that the operation with the brush shredder in the pre-harvest also aimed at leveling the soil to facilitate the collection of coffee in the sweeping process (Tavares, 2016). Thus, this operation revolved the soil surface in a layer approximately $2.0 \mathrm{~cm}$ deep.

The herbicides were applied on both sides of the coffee row, in strips whose width was approximately $1.4 \mathrm{~m}$, starting under the bottom of the plant canopy (approximately $0.50 \mathrm{~m}$ from the trunk) and projecting up to half spacing of the corresponding inter-row. In the application, a tractor (Valtra BF 75) and sprayer (Jet PH 400) set was used, with protected bars for application in a directed jet. The equipment contained JDF 110.015 Jacto jet impact spray tips spaced $0.5 \mathrm{~m}$ in the bar, which was kept $0.5 \mathrm{~m}$ away from the target, at a pressure of 3.0 bar and speed of $5.4 \mathrm{~km} \mathrm{~h}^{-1}$, resulting in an application rate equivalent to $222 \mathrm{~L} \mathrm{ha}^{-1}$. The average meteorological conditions at the moment of application were measured with a conventional psychrometer and a portable digital anemometer and presented values of wind speed of 
$3.32 \mathrm{~km} \mathrm{~h}^{-1}$, air humidity of $70 \%$ and average air temperature of $21^{\circ} \mathrm{C}$.

The phytosociological survey of weed species in the experimental area as a whole (before the placement of the experimental plots and application of the herbicides) was carried out in late May, using eight samples with an inventory table $(0.3 \mathrm{~m} \times 0.3 \mathrm{~m})$ launched randomly close to the bottom of the coffee plants. Weeds were collected, separated by species, identified, counted and dried in an oven with air circulation and renewal for three days at $70^{\circ} \mathrm{C}$, to determine the dry matter mass per land area. Then, the following parameters were estimated: frequency, density, abundance, relative frequency, relative density, relative abundance and, finally, the importance value index - IVI (Curtis and Mclntosh, 1950).

After 21 days of application (DAA) of herbicides in pre-emergence (6/25/2012) and also approximately one month after the beginning of the rainy season (on $5 / 11 / 2012$, at $154 \mathrm{DAA})$, the residual effect of the herbicides was evaluated by sampling the weed species that germinated in the inter-rows, near to the bottom of the coffee plants, as described in Ronchi and Silva (2004).

Before the application of the herbicides, therefore at the end of May 2012, the number of stem nodes present in the apical region (last $10 \mathrm{~cm}$ ) of the orthotropic branch and the number of reproductive nodes present in two plagiotropic branches also in the apical region of the coffee plant, were marked and counted in ten plants per plot. In December 2012, a new node count was made for these two dimorphic types of branches. Then, it was estimated the increase in plant growth in the period, by the difference between the final and initial value of each variable, aiming to detect possible influence of herbicides on coffee growth in the long term.

\subsection{Experiment 2}

In experiment 2, a non-irrigated coffee crop (Coffea arabica cv. Catuaí Vermelho IAC 144) was used, aged 18 , implanted at $4.0 \times 0.5 \mathrm{~m}$ spacing. At the time of the test, the crop had $2.0 \mathrm{~m}$ of canopy diameter, approximately $4.0 \mathrm{~m}$ in height, and without weeds under the coffee plant canopy. It was tested tank mixtures of pre-emergent and post-emergent nonselective herbicide (glyphosate) in the pre-harvest of coffee. It was considered appropriate to make this association in a tank, since the percentage of soil covered by weeds was low $(37 \pm 3.0 \%)$ and the plants were young, approximately $0.1 \mathrm{~m}$ tall (different the situation of experiment 1), allowing the sprayed herbicide solution to reach the soil as a priority.

The experimental design used was randomized blocks with five treatments and four replicates. The experimental units consisted of a $10 \mathrm{~m}$ long coffee inter-rows, delimited laterally by the bottom of the coffee plant canopy, totaling the application area of $20.0 \mathrm{~m}^{2}$. The treatments consisted of: control (without weed control in the pre-harvest); glyphosate $(0.54 \mathrm{~kg}$ a.i. ha-1); glyphosate + oxyfluorfen $(0.54+$ $0.72 \mathrm{~kg}$ a.i. ha $\left.{ }^{-1}\right)$; glyphosate + sulfentrazone $(0.54+$ $0.40 \mathrm{~kg}$ a.i. ha-1); and glyphosate + sulfentrazone $\left(0.54+0.60 \mathrm{~kg}\right.$ a.i. $\left.\mathrm{ha}^{-1}\right)$. In all treatments, mineral

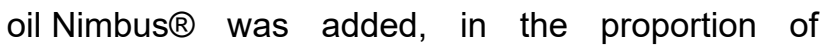
$0.5 \% \mathrm{v} / \mathrm{v}$, except for the treatment with isolated glyphosate.

The application was made on June 2, 2012, with a backpack $\mathrm{CO}_{2}$ pressurized precision sprayer, with constant pressure of 3.0 bar, and a spray volume of $212 \mathrm{~L} \mathrm{ha}^{-1}$. The sprayer boom was kept at $0.6 \mathrm{~m}$ above the ground, with four TeeJet XR11003 sprayer nozzles, spaced $0.50 \mathrm{~m}$. The application was performed in a jet directed to the inter-rows, but without preventing drift to occur to the bottom of the coffee tree. The operation was carried out between 7 and 9 hours, under temperature and relative humidity of $21^{\circ} \mathrm{C}$ and $65 \%$, respectively, measured with a conventional psychrometer.

The survey of weed species was done in early June, before the herbicide applications, as described in experiment 1. After the beginning of the rainy season, on October 10, 2012 (at 130 DAA), the residual effect of the herbicides was evaluated also by sampling the weed species that emerged in the plots, as described for experiment 1. On those same times, the percentage of soil covering by weed was simultaneously assessed, giving visual notes: $100 \%$ total soil cover; and zero - absence of weeds in the plot.

The efficacy of the treatments on the weed control was evaluated at $7,14,21$ and 28 DAA, with percentage scores of control in relation to the control treatment, with zero being the absence of control and 100 , the death of the plant. For better interpretation of the results, weed control levels were classified according to the Asociación Latinoamericana de Malezas - ALAM (1974), with some modifications: from $91 \%$ to $100 \%$, very high control; $81 \%$ to $90 \%$, high control; $71 \%$ to $80 \%$, reasonable control; $51 \%$ to $70 \%$, insufficient control; and, when less than $50 \%$, poor control. 


\subsection{Statistical analysis}

The normality and homoscedasticity of the errors were checked with the Lilliefors and Cochran tests, together with the graphical analysis of residues (Neter et al., 1990). The weed density and dry matter data in experiment 1 , and the weed dry matter data in experiment 2 , were transformed to $\sqrt{ }(X+1.0)$. Then, they were subjected to analysis of variance, and to multiple comparisons of means, using the Tukey test at $10 \%$ probability. In the second experiment, when evaluating the percentage of control, the "control" treatment was excluded from the analysis of variance. When not reported in the graph or table, some variables were submitted to descriptive analysis only. SAEG software version 9.0 was used for the analyzes.

\section{RESULTS AND DISCUSSION}

\subsection{Experiment 1}

Immediately before either glyphosate desiccation or brush shredder operation in the pre-harvest of coffee, 14 weed species were identified in the experimental area: Amaranthus viridis, Bidens pilosa, Urochloa plantaginea, Chamaesyce hirta, Commelina benghalensis, Coronopus didymus, Digitaria horizontalis, Eleusine indica, Emilia fosberjii, Euphorbia heterophylla, Leonurus sibiricus, Lipidium virginicum, Oxalis latifolia and Sida rhombifolia. These species, common in coffee areas in the Cerrado of Minas Gerais (Araújo et al., 2012; Magalhães et al., 2012), promoted coverage of $100 \%$ of the soil surface and totalized density and shoot dry matter of 437 plants $\mathrm{m}^{-2}$ and $270 \mathrm{~g} \mathrm{~m}^{-2}$, respectively. Despite this floristic diversity, the five main species in the experimental area, responsible for $83 \%$ of both density and total shoot dry matter, based on the importance value index (IVI), in decreasing order, were $A$. viridis, D. horizontalis, E. fosbergii, B. pilosa and $U$. plantaginea (Figure $1 \mathrm{~A}$ ).

Comparing the pre-harvest management systems, brush shredder versus desiccation, without soilapplied herbicides, it was found that both managements controlled $100 \%$ of the described vegetation. However, unlike desiccation, the use of the brush shredder stimulated rapid weed reinfestation, initially by the $O$. latifolia, since it multiplied and disseminated its proxpagules. This suggests that brush use should be restricted in the presence of species that have underground propagation structures, if the soil is disturbed. Thus, considering that the $O$. latifolia infestation was uneven in the brushed plots and that there was no emergence of such weed specie in the desiccated areas, due to the non-revolving soil, the plants of $O$. latifolia were removed early from all plots by manual plucking, to allow control assessment of other weed species.

In the first sampling, performed 21 days after the application (DAA) of the treatments, there was a slight change in the weed community in relation to that initially described, with the appearance of seven new species in the area, represented by: Galinsoga parviflora, G. quadriradiata, Richardia brasiliensis, Spermacoce latifolia, Gamochaeta coarctata, Phyllanthus amarus and Portulaca oleracea. However, at that time, the five main species, which together represented $85 \%$ of the density and total dry matter, were A. viridis, B. pilosa, $E$. heterophylla, D. horizontalis and U. plantaginea (Figure 2). This infestation occurred mainly due to
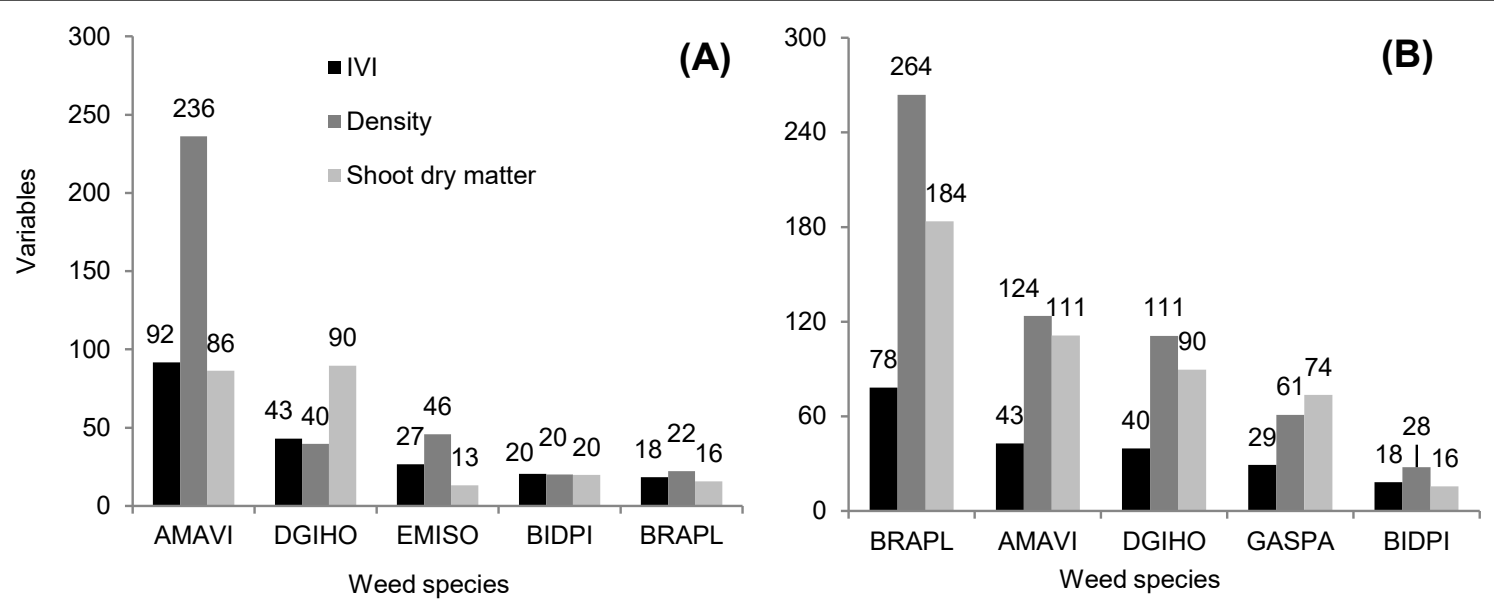

AMAVI: A. viridis; DGIHO: D. horizontalis; EMISO: E. fosbergii, BIDPT: B. pilosa; BRAPL: U. plantagniea; GASPA: G. parviflora.

Figure 1 - Importance value index (IVI), density (plants $\mathrm{m}^{-2}$ ) and shoot dry matter $\left(\mathrm{g} \mathrm{m}^{-2}\right)$ of the five main weed species in the experimental areas in experiments $1(A)$ and $2(B)$, before applying the treatments. 
new emergencies, due to the superficial turning of the soil by the brush shredder, associated with the occurrence of rains in June (Figure $3 A$ and $B$ ), and also, but to a lesser extent, due to the regrowth of the underground parts or stems of the adult plants partially crushed by brushing. In the area desiccated with glyphosate, even with available soil moisture (Figure 3B), there was low infestation in the first weed sampling (Figure 2), due to the non-revolving soil.

In a first analysis, these results indicate that the application of herbicides in pre-emergence is unnecessary to weed control after desiccation in Cerrado crops, especially if there is no rain in the post-desiccation and pre-harvest period, as well as if the desiccation is carried out close to harvest timing. In this case, only desiccation (glyphosate) would ensure the desirable weed-free condition during the coffee harvesting (Santinato et al., 2016). However, the application of pre-emergence oxyfluorfen or sulfentrazone in pre-harvest, after either brush or desiccation operations, contributed to the weed

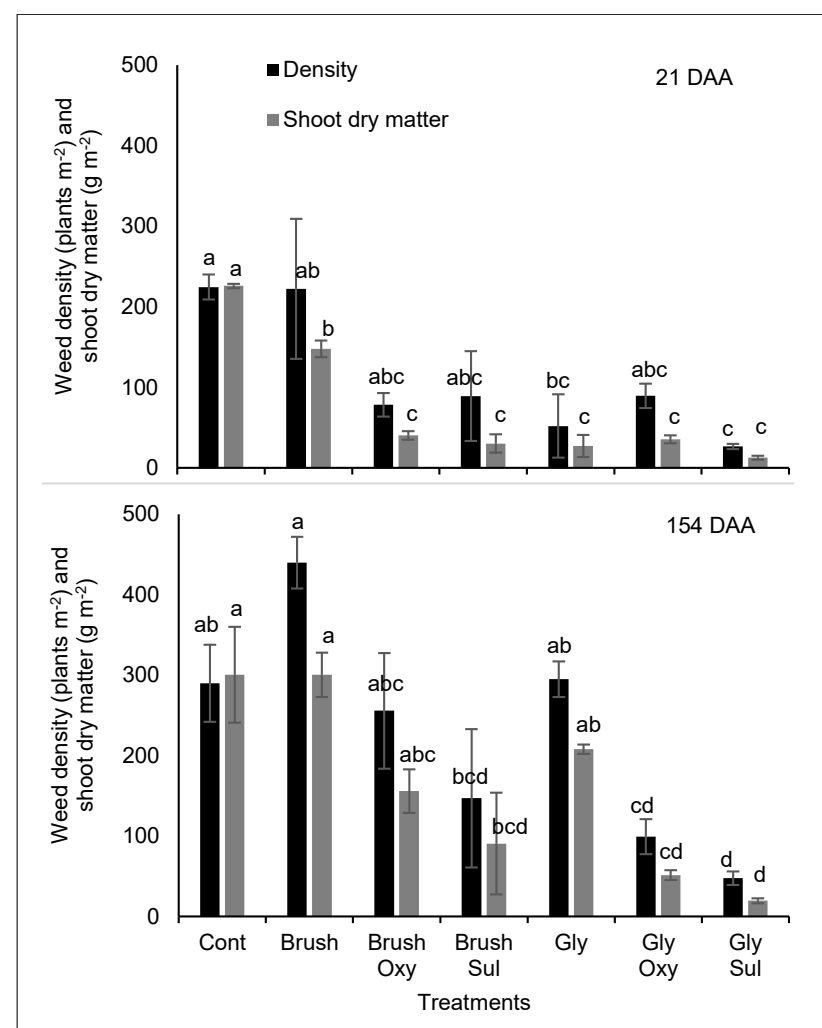

Each bar represents the mean \pm standard error of the mean $(n=3)$. For each season and variables, means followed by the same letter are statistically equal by the Tukey test at $10 \%$ probability. The $P$ value associated with the $F$ value for density and dry matter was equal to 0.03169 and 0.00001 at $21 \mathrm{DAA}$ and 0.00026 and 0.00015 at $154 \mathrm{DAA}$, respectively. Cont: control; Brush: brush shredder; Oxy: oxyfluorfen; Sul: sulfentrazone; Gly: glyphosate.

Figure 2 - Density and total shoot dry matter of weeds in two seasons: at 21 days after application (DAA) of the herbicides in pre-emergence, and at 154 DAA, in the first week of November.

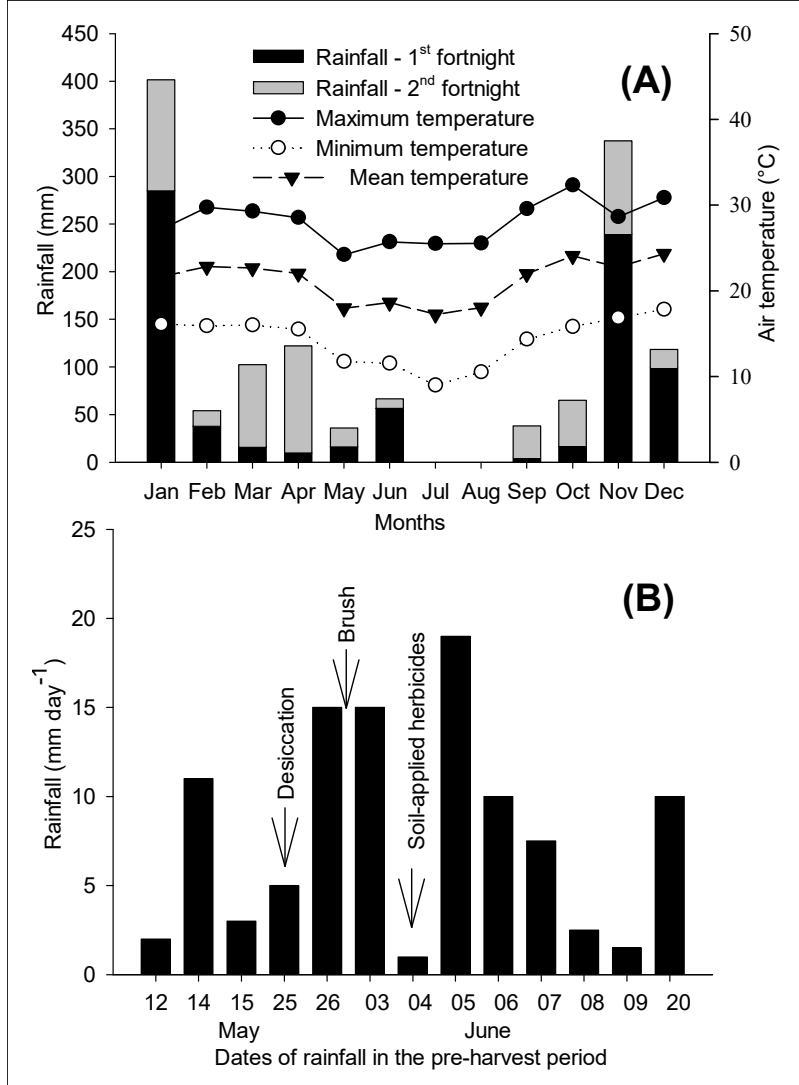

Coffee harvesting took place in mid-July and sweeping process of ground coffee in early August.

Figure 3 - Air temperature and rainfall from January to December 2012 (A) and dates of rainfall in the preharvest period $(B)$.

control in the crop: after brushing, they reduced weed dry matter respectively by $76 \%$ at 21 DAA and $59 \%$ at $154 \mathrm{DAA}$; and, after desiccation, the reduction was $11 \%$ at $21 \mathrm{DAA}$ and $83 \%$ at $154 \mathrm{DAA}$, respectively (Figure 2).

It is noteworthy to note that oxyfluorfen and, especially, sulfentrazone, applied (in the pre-harvest) after desiccation, guaranteed less weed infestation in the coffee crop at the beginning of the rainy season (at $154 \mathrm{DAA}$ ), compared to desiccation only (Figure 2). At that time, the aforementioned species (A. viridis, B. pilosa, E. heterophylla, D. horizontalis and $U$. plantaginea) represented $91 \%$ of the infestation (Figure 2). Thus, it can also be inferred that the first weed management operation at the beginning of the rainy season could be performed later, due to the residual activity of the soil-applied herbicides at that time, especially sulfentrazone. This long-term residual effect resulted from the probable low degradation of herbicides in the soil, due to the long dry and cold period (Brum et al., 2013) between July and September (Figure 3).

At 21 DAA, considering the brush shredder as a control treatment, there was a reduction in weed 
density and total shoot dry matter of $65 \%$ and $73 \%$, respectively, with the application of oxyfluorfen, and of $60 \%$ and $80 \%$, with the application of sulfentrazone (Figure 2). At 154 DAT, such reductions were $42 \%$ and $48 \%$ with oxyfluorfen, and $66 \%$ and $70 \%$ with sulfentrazone, respectively (Figure 2 ). In the case of the application of these herbicides after desiccation, there was unsatisfactory control with oxyfluorfen at 21 DAA (Figure 4), but the density and dry matter of total weeds were reduced by $48 \%$ and $52 \%$ with the application of sulfentrazone. At $154 \mathrm{DAA}$, reductions in weed density and dry total shoot matter were $66 \%$ and $76 \%$, respectively, with the application of oxyfluorfen and $84 \%$ and $91 \%$ with sulfentrazone, after desiccation. Thus, in the first month after application, both herbicides showed similar control efficacy, with the exception of $B$. pilosa by oxyfluorfen, as already observed in coffee (Ronchi and Silva, 2004), however, in the beginning of the rainy season, sulfentrazone stood out in relation to oxyfluorfen, which was somewhat expected, due to its greater residual effect.

The effectiveness of herbicide control could also be analyzed separately by species, particularly for those of greater predominance in the area, and in the system subjected to the brush shredder, whose
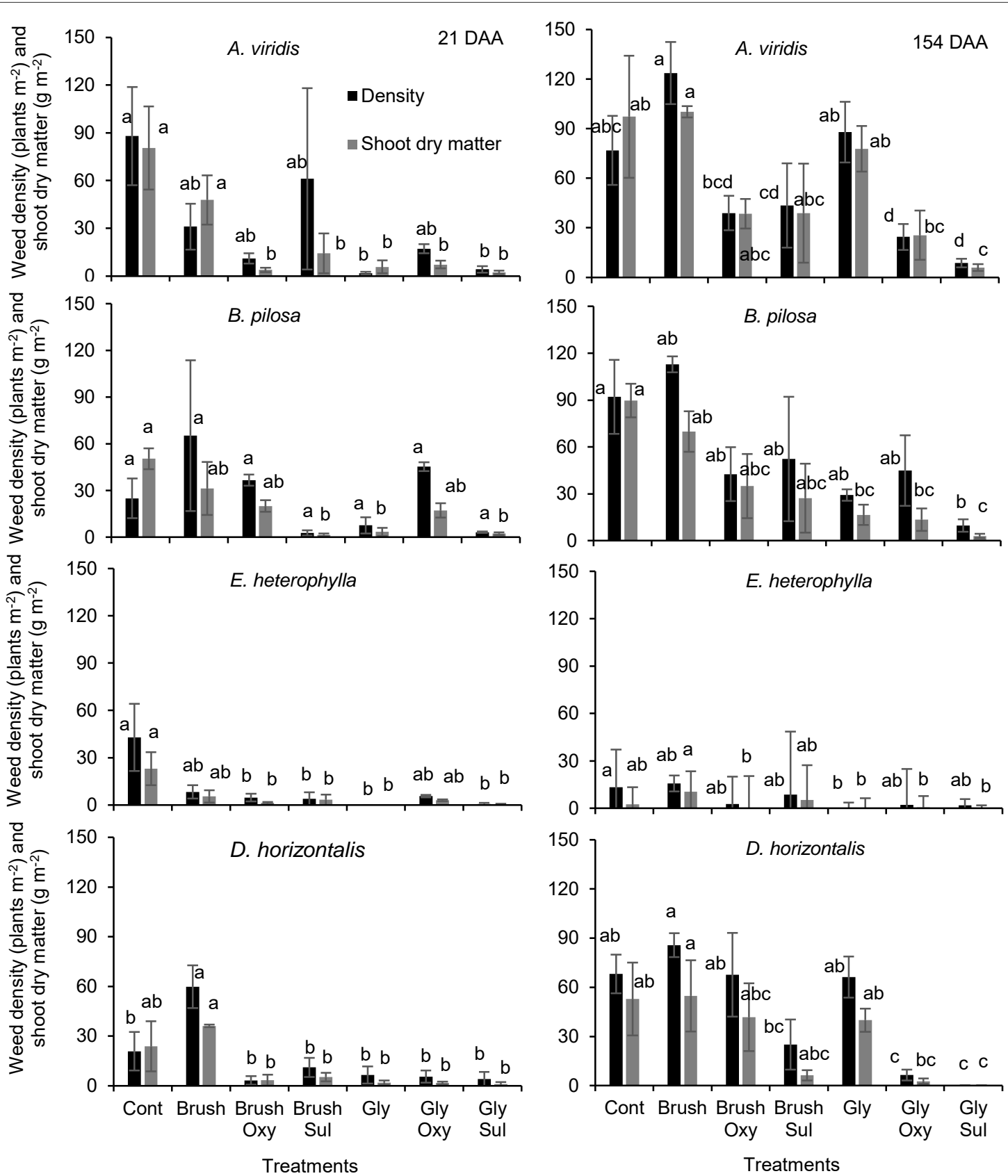

Each bar represents the mean \pm standard error of the mean $(n=3)$. For each variable, means followed by the same letter do not differ, they are equal by the Tukey test at $10 \%$ probability. (Cont: control; Brush: brush shredder; Oxy: oxyfluorfen; Sul: sulfentrazone; Gly: glyphosate).

Figure 4 - Density and shoot dry matter of the main species of weeds at 21 days after application (DAA) and at the beginning of the rainy season (at $154 \mathrm{DAA}$ ). 
infestation was greater compared to the desiccated plots (Figure 4). Thus, it was found that oxyfluorfen and sulfentrazone respectively reduced the shoot dry matter of $A$. viridis by $92 \%$ and $70 \%$; in $36 \%$ and $95 \%$ that of B. pilosa; in $76 \%$ and $40 \%$ that of E. heterophylla; and in $91 \%$ and $85 \%$ that of $D$. horizontalis, at 21 DAA (Figure 4). Even after five months (at $154 \mathrm{DAA}$ ) of herbicide application in pre-emergence, there was still a residual effect. Therefore, oxyfluorfen and sulfentrazone both reduced the shoot dry matter of $A$. viridis by $62 \%$; in $50 \%$ and $61 \%$ that of B. pilosa; in $100 \%$ and $50 \%$ that of E. heterophylla; and in $24 \%$ and $85 \%$ that of D. horizontalis, respectively (Figure 4).

Since a sprayer boom with a drift protector was used for the pre-emergent herbicides' application, which was performed under the coffee plant canopy, there were no visual symptoms of intoxication by direct drift of the herbicides to the coffee tree, which would be easily identifiable based on the description of Magalhães et al. (2012). In addition, no treatment affected growth of the orthotropic and plagiotropic stems in the apical region of the coffee tree (Figure 5). It is worth remembering that the number of reproductive nodes in the plagiotropic branch is an important physiological component of coffee yield (DaMatta et al., 2007), and that the appearance of new plagiotropic branches in the apical region of the coffee tree depends on the activity of the buds-ofthe-series presented in the newly-formed nodes in the orthotropic stem (Clowes and Allison, 1982). These positive selectivity results from directed jet

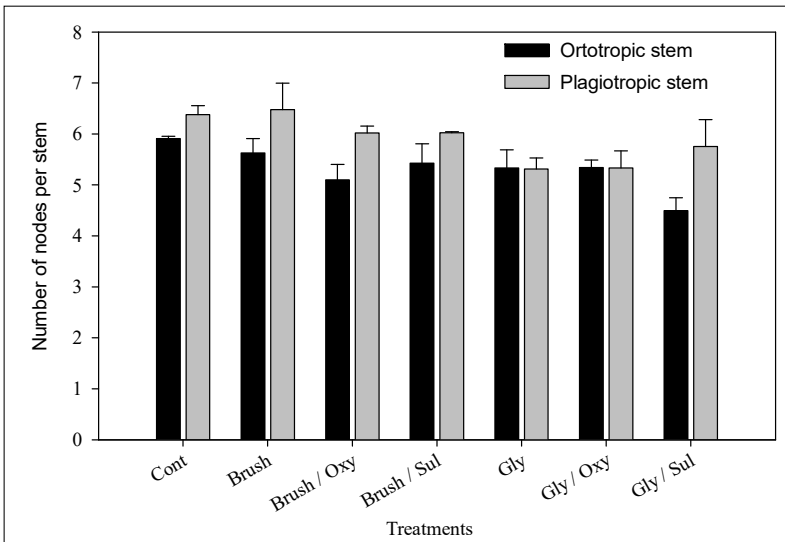

The bars refer to the mean \pm standard error of the mean $(n=3)$. Cont: control; Brush: brush shredder; Oxy: oxyfluorfen; Sul: sulfentrazone; Gly: glyphosate. F test not significant at $5 \%$ probability. The coefficients of variation of the orthotropic and plagiotropic branches were 8.48 and 9.60, respectively.

Figure 5 - Average increase in the number of nodes in the orthotropic and plagiotropic stems of the apical region of coffee tree, in the interval between June and December 2012. application, added to the control data discussed earlier, support the use of these two herbicides, already registered to be used in adult coffee (Rodrigues and Almeida, 2018), for weed control at the pre-harvesting time of the coffee crop.

Even though coffee trees grown in the Cerrado areas have a root system concentrated in the superficial layers of the soil (Ronchi et al., 2015), it is possible that the absorption of herbicides (oxyfluorfen and sulfentrazone) was also minimal or null by the roots. As shown in Table 1, the soil had high levels of organic matter, CTC and clay, and there was low rainfall in the months following application (Figure 3). In an integrated manner, these characteristics tend to promote high sorption (therefore, low leaching) of herbicides in the soil (Brum et al., 2013; Freitas et al., 2014; Passos et al., 2013). This, even for sulfentrazone, which has a high half-life and low Koc and which, because it is derived from weak acid (Martinez et al., 2008; Rodrigues and Almeida, 2018), would present greater movement in a soil with high $\mathrm{pH}$, as in the present trial (Table 1).

\subsection{Experiment 2}

In this test, 16 weed species were found in the field at the time of application: A. viridis, B. pilosa, C. hirta, C. benghalensis, C. didymus, D. horizontalis, E. indica, E. fosberjii, E. heterophylla, L. sibiricus, L. virginicum, S. latifolia, G. coactata, P. amarus, $P$. oleracea and $U$. plantaginea, totaling density and shoot dry matter of 692 plants $\mathrm{m}^{-2}$ and $526 \mathrm{~g} \mathrm{~m}^{-2}$, respectively. Despite this diversity, the five main species in the experimental area, based on the importance value index (IVI), in decreasing order, were U. plantaginea, A. viridis, D. horizontalis, G. parviflora and $B$. pilosa (Figure 1B). Alone they were responsible for $85 \%$ and $90 \%$ of the total weed density and shoot dry matter, respectively, and provided an average soil coverage of $37 \%$ (Table 2 ).

Since the tank-mixture herbicide applications were done in a range of $2.0 \mathrm{~m}$ between the lines, at a height of $0.6 \mathrm{~m}$ from the ground, there was a drift of the herbicides oxyfluorfen and sulfentrazone to the coffee tree, but not evenly in all experimental plots. As they are Protox inhibiting herbicides (Hess and Weller, 2000), the symptoms were characterized, 14 days after application, basically by necrosis in the leaf blade (as already reported for coffee by Magalhães et al., 2012). However, it is worth mentioning that there were very slight injuries and only in some leaves of some branches of the coffee tree's bottom, therefore practically insignificant in front of the entire 
canopy of a $4.0 \mathrm{~m}$ tall coffee tree. It was an old coffee crop, which had already lost some plagiotropic branches at its bottom due to the repeated mechanized harvests and also due to the natural loss (Pereira et al., 2007).

With the exception of treatment with isolated glyphosate (reasonable control), all tank mixtures were highly effective in controlling weeds in postemergence, with control greater than $97 \%$ at 28 DAA (Table 2). Control was faster with $0.6 \mathrm{~kg}$ a.i. ha-1 of sulfentrazone. In the following months, a dry period predominated (Figure 3), with no new emergencies. However, with the rains that occurred in September and, especially, in October, despite being of low intensity (Figure 3A), the soil seed bank was stimulated and a new infestation occurred in the experimental area, providing soil coverage of $71 \%$ in the inter-rows, in the treatment without weeding (Figure 6A). The species that occurred in the area at this time were A. viridis, B. pilosa, D. horizontalis, E. indica, G. coactata, I. grandifolia, L. virginicum and U. plantaginea, totaling 172 plants $\mathrm{m}^{-2}$ and $95 \mathrm{~g} \mathrm{~m}^{-2}$. Of this total, $94 \%$ and $91 \%$ of the weed density and shoot dry matter, respectively, were composed of grass species, and the rest, by broadleaf weeds.

Thus, the percentage of soil cover was inferred to $10 \%$ in the treatments with sulfentrazone, among which there was no difference (Figure 6A). This did not occur in treatments with glyphosate alone or in mixture with oxyfluorfen, whose soil cover was $46 \%$ and $63 \%$, respectively (Figure $6 \mathrm{~A}$ ), and statistically equal to that of the control treatment (with $71 \%$ ). Sulfentrazone at doses of 0.4 or $0.6 \mathrm{~kg}$ a.i. ha ${ }^{-1}$ reduced $(P<0.10)$ the weed density and shoot dry matter, on average, $77 \%$ and $86 \%$, respectively, while no reduction in weeds was observed (in October) in treatments with glyphosate alone or in mixture with oxyfluorfen (Figure 6B).

Therefore, treatments with sulfentrazone, regardless of the dose, showed sufficient residual to

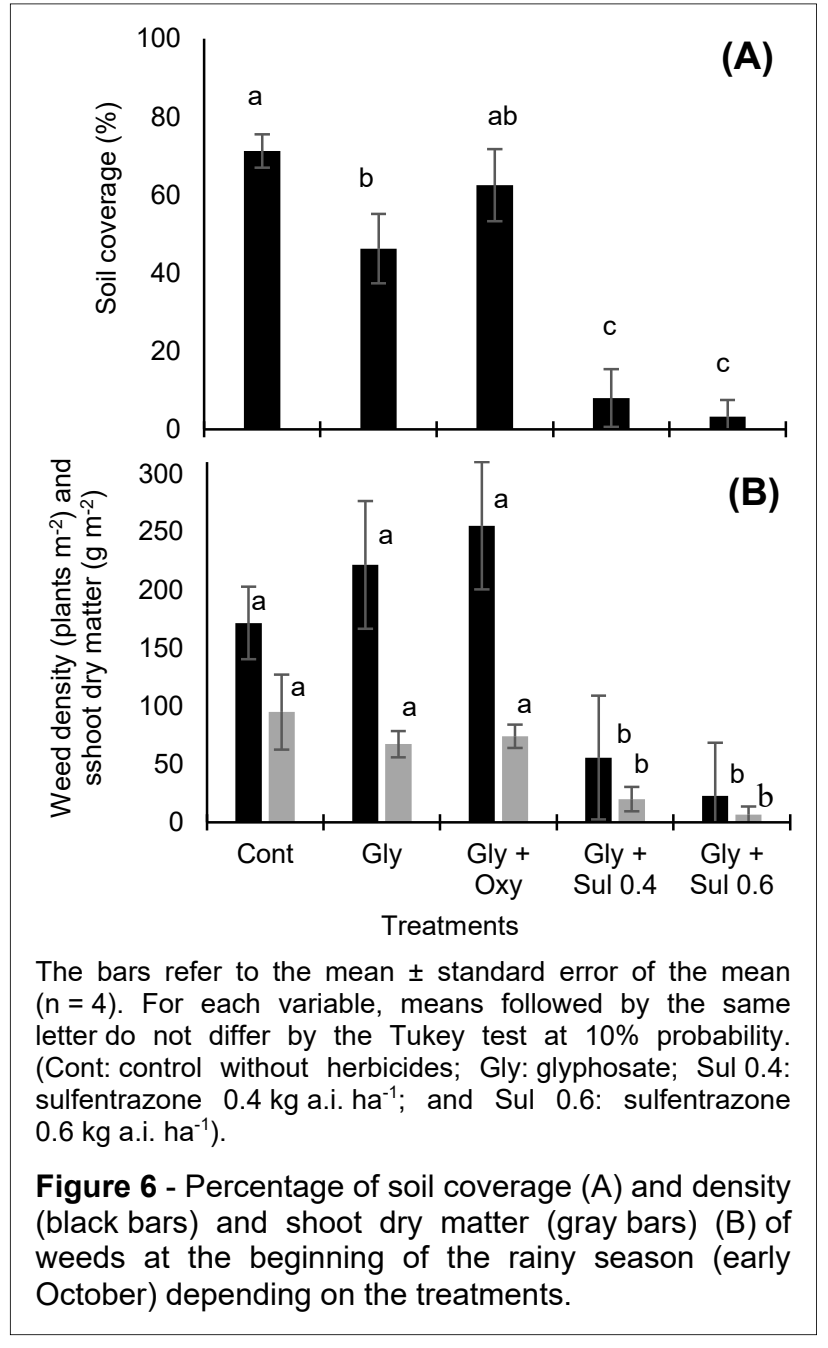

minimize reinfestation at the beginning of the rainy season. It should be noted that this may not be a standard response, as the behavior of sulfentrazone in the soil depends not only on the physical and chemical characteristics of the soil (Freitas et al., 2014; Passos et al., 2013) and microbial activity (Vivian et al., 2006), but also on its tank mixture with glyphosate and, more specifically, on the glyphosate formulation used, as recently demonstrated by Langaro (2018). Anyway, tank mixing is an important tool for weed management, already adopted for crops such as soybean (Gazziero, 2015; Minozzi et al., 2014), and which could be extended to coffee.

Table 2 - Percentage of soil coverage at the time of application and percentage of weed control at 7, 14, 21 and 28 days after application (DAA) of herbicides in tank-mixture, in experiment 2

\begin{tabular}{|c|c|c|c|c|c|}
\hline \multirow{2}{*}{ Treatment } & \multirow{2}{*}{$\begin{array}{c}\text { Soil coverage } \\
(\%)\end{array}$} & \multicolumn{4}{|c|}{ Weed control (\%) } \\
\hline & & 7 DAA & 14 DAA & $21 \mathrm{DAA}$ & 28 DAA \\
\hline Control (no herbicides) & 38.8 a & 0.0 & 0.0 & 0.0 & 0.0 \\
\hline Glyphosate (0.54 kg i.a. ha-1) & $35.1 \mathrm{a}$ & $50.0 \mathrm{~b}$ & $52.5 \mathrm{~b}$ & $62.5 \mathrm{~b}$ & $66.3 \mathrm{~b}$ \\
\hline Glyphosate+oxyfluorfen $\left(0.54+0.72\right.$ kg i.a. ha $\left.{ }^{-1}\right)$ & $39.8 \mathrm{a}$ & $73.8 \mathrm{a}$ & 75.0 a & $75.0 \mathrm{ab}$ & $97.8 \mathrm{a}$ \\
\hline Glyphosate+sulfentrazone $\left(0.54+0.40\right.$ kg i.a. ha $\left.{ }^{-1}\right)$ & 39.6 a & $63.8 \mathrm{ab}$ & $68.8 \mathrm{ab}$ & $67.5 \mathrm{~b}$ & $99.5 \mathrm{a}$ \\
\hline Glyphosate+sulfentrazone $\left(0.54+0.60 \mathrm{~kg}\right.$ i.a. ha $\left.{ }^{-1}\right)$ & $33.1 \mathrm{a}$ & $76.3 \mathrm{a}$ & $82.5 \mathrm{a}$ & $84.3 \mathrm{a}$ & $100.0 \mathrm{a}$ \\
\hline Average & 37.3 & 65.9 & 69.7 & 72.3 & 90.9 \\
\hline $\mathrm{CV}(\%)$ & 30.04 & 11.46 & 12.33 & 8.81 & 3.31 \\
\hline
\end{tabular}

Column averages followed by the same letter do not differ by Tukey's test at $10 \%$ probability. 
Taken together, the results of this work allow us to consider that the management of weeds in the preharvest of coffee in the Cerrado of Minas Gerais requires an association of control methods, as recommended by the integrated management system (Bajwa, 2014; Ronchi and Silva, 2018). If the coffee producer chooses to use the brush shredder in the pre-harvest and it rains during this period, the reinfestation of the area is likely to occur before the harvest. In this case, either non-selective herbicides, applied in post-emergence, just before harvest, or oxyfluorfen or sulfentrazone, applied in preemergence of weeds immediately after using the brush shredder, could be applied. Currently, there are other herbicides that could also be used in preemergence (Rodrigues and Almeida, 2018) for this purpose.

Despite the possibility of tank-mixture with glyphosate and the residual effect of these herbicides (especially sulfentrazone) at the beginning of the rainy season, pre-emergent herbicides might be unnecessary when the desiccation operation happens too close to the harvesting.

\section{Conclusions}

Sulfentrazone and oxyfluorfen were effective on the weed control in the pre-harvest of the coffee crop, mainly when applied after brush shedder operations.

The soil-applied herbicides may be unrequired for the weed control in the pre-harvest of the coffee crop, if desiccation is carried out just before the coffee harvest.

\section{CONTRIBUTIONS}

The corresponding author was responsible for all the work.

\section{ACKNOWLEDGEMENTS}

I thank the Fazenda Transagro S.A., for extending the use of the experimental area. I also thank CAPES (Coordenação de Aperfeiçoamento de Pessoal de Nivel Superior), for the financial support for English translation.

\section{REFERENCES}

Araújo FC, Ronchi CP, Almeida WL, Silva MAA, Magalhães CEO, Good-God PIV. Optimizing the width of strip weeding in arabica coffee in relation to crop age. Planta Daninha. 2012;30:129-38.

Asociación Latinoamericana de Malezas - ALAM. Recomendaciones sobre unificación de los sistemas de evaluacion en ensyos de control de malezas. ALAM. 1974;1:35-8.
Bajwa AA. Sustainable weed management in conservation agriculture. Crop Prot. 2014;65:105-13.

Blanco HG, Oliveira DA, Pupo EIH. Período de competição de uma comunidade natural de mato em uma cultura de café em formação. Biológico. 1982;48:9-20.

Brum CS, Franco AA, Scorza Junior RP. Degradação do herbicida sulfentrazone em dois solos de Mato Grosso do Sul. Rev Bras Eng Agríc Amb. 2013;17:558-64.

Clowes MSJ, Allison JCS. A review of the coffee plant (Coffea arabica L.), its environment and management in relation to coffee growing in Zimbabwe. Zimbabwe J Agric Res. 1982;20:1-19.

Companhia Nacional de Abastecimento - CONAB. Acompanhamento da safra brasileira de café: segundo levantamento - maio de 2019. [acesso em: 11 ago 2019]. Disponível em: https://www.conab.gov.br/infoagro/safras/cafe.

Curtis JT, Mclntosh RP. The interrelations of certain analytic and synthetic phytosociological characters. Ecology. 1950;31:434-55.

DaMatta FM, Ronchi CP, Maestri M, Barros RS. Ecophysiology of coffee growth and production. Braz J Plant Physiol. 2007;19:485-510.

Fernandes ALT, Partelli FL, Bonomo R, Golynski A. A moderna cafeicultura dos Cerrados Brasileiros. Pesq Agropec Trop. 2012;4:231-40.

Fernandes ALT, Tavares TO, Santinato F, Ferreira RT, Santinato R. Viabilidade técnica e econômica da irrigação localizada do cafeeiro, nas condições climáticas do planalto de Araxá, MG. Coffee Sci. 2016;11:346-57.

Freitas MAM, Passos ABRJ, Torres LG, Moraes HMF, Faustino LA, Rocha PRR, et al. Sorção do sulfentrazone em diferentes tipos de solo determinada por bioensaios. Planta Daninha. 2014;32:385-92.

Gazziero DLP. Misturas de agrotóxicos em tanque nas propriedades agrícolas do Brasil. Planta Daninha. 2015;33:83-92.

Hess FD, Weller SC. Inhibitors of protoporphyrinogen oxidase: diphenyl ethers and oxadiazon. In: Herbicide action. West Lafayette: Purdue University; 2000.

Langaro AC. Sorção e lixiviação do sulfentrazone em latossolo vermelho-amarelo aplicado de forma isolada e em mistura com formulações de glyphosate [tese]. Viçosa: Universidade Federal de Viçosa; 2018.

Lemes LN, Carvalho LB, Souza MC, Alves PLCA. Weed interference on coffee fruit production during a four-year investigation after planting. Afr J Agric Res. 2010;5:112843.

Magalhães CEO, Ronchi CP, Ruas RAA, Silva MAA, Araújo FC, Almeida WL. Seletividade e controle de plantas daninhas com oxyfluorfen e sulfentrazone na implantação de lavoura de café. Planta daninha. 2012;30:607-16.

Martinez CO, Silva CMMS, Fay EF, Abakerli RB, Maia AHN, Durrant LR.The effects of moisture and temperature on the degradation of sulfentrazone. Geoderma. 2008;147:56-62.

Matiello JB, Santinato R, Garcia AWR, Almeida SR, Fernandes DR. Cultura de café no Brasil: manual de recomendações. ed. 2015. São Paulo: Futurama Editora; 2016. 
Minozzi GB, Monquero PA, Pereira PA. Eficácia de diferentes manejos das plantas daninhas na cultura da soja transgênica. Rev Bras Ci Agr. 2014;9:406-12.

Neter J, Wasserman W, Kutner MH. Applied linear statistical models: regression, analysis of variance and experimental designs. Homewood: Richard A. Irwin; 1990.

Passos ABRJ, Freitas MA, Torres LG, Silva AA, Queiroz ME, Lima CF. Sorption and desorption of sulfentrazone in Brazilian soils. J Environ Sci Health. 2013;48:646-50.

Pereira SP, Guimarães RJ, Bartholo GF, Guimarães PTG, Alves JD. Crescimento vegetativo e produção de cafeeiros (Coffea arabica L.) recepados em duas épocas,

conduzidos em espaçamentos crescentes. Ciênc Agrotec. 2007; 31:643-49.

Rodrigues BN, Almeida FLA. Guia de herbicidas. 7. ed. Londrina, PR: Edição dos Autores; 2018.

Ronchi CP, Sousa Júnior JM, Ameida WL, Souza DS, Silva NO, Oliveira LB, et al. Morfologia radicular de diferentes cultivares de café arábica submetidas a diferentes arranjos espaciais. Pesq Agropec Bras. 2015;50:187-95.

Ronchi CP, Silva AA. Sustainable weed control in coffee. In: Korres N, Burgos NR, Duke SO, editors. Weed control: sustainability, hazards and risks in cropping systems worldwide. Boca Raton, USA: Science Publishers; 2018.

Ronchi CP, Silva AA. Weed control in young coffee plantations through post-emergence herbicide application onto total area. Planta Daninha. 2004;22:607-15.

Ronchi CP, Silva AA. Effects of weed species competition on the growth of young coffee plants. Planta Daninha. 2006;24:415-23.

Santinato R, Fernandes ALT, Fernandes DR. Irrigação na cultura do café. 2. ed. Belo Horizonte: O Lutador; 2008.

Santinato R, Santinato F, Dornelas G, Duarte $\mathrm{SP}$, Carvalho R. Uso do herbicida goal (oxyfluorfen) em área total das entrelinhas do cafezal, visando a colheita mecanizada do café de chão. In: Congresso Brasileiro de Pesquisas Cafeeiras. 2016. p.216-17.

Tavares TO. Recolhimento mecanizado do café em função do manejo do solo e da declividade do terreno [dissertação]. Jaboticabal: Universidade Estadual Paulista, Faculdade de Ciências Agrárias e Veterinárias; 2016.

Vivian R, Reis MR, Jakelaitis A, Silva AF, Guimarães AA, Santos JB, et al. Persistência de sulfentrazone em Argissolo Vermelho-Amarelo cultivado com cana-deaçúcar. Planta Daninha. 2006;24:741-50. 